\title{
MODEL INTERVENSI FUNGSI STEP UNTUK PERAMALAN HARGA SAHAM PT. GARUDA INDONESIA (PERSERO) TBK DI MASA PANDEMI COVID-19
}

\author{
SEPTRI DAMAYANTI ${ }^{1 *}$, SISKA YOSMAR ${ }^{2}$ \\ ${ }^{1,2}$ Prodi S1 Matematika FMIPA Universitas Bengkulu \\ *septridamayanti@unib.ac.id
}

\begin{abstract}
ABSTRAK
Sektor industri penerbangan Indonesia mengalami dampak negatif yang cukup hebat akibat COVID19. Hal tersebut membuat performa finansial maskapai-maskapai di Indonesia memburuk, terutama berimbas kepada merosotnya close price index industri penerbangan milik pemerintah, khususnya PT. Garuda Indonesia (Persero) Tbk (GIAA). Model intervensi merupakan suatu model time series yang digunakan untuk memodelkan dan meramalkan data yang mengandung intervensi baik dari faktor internal maupun eksternal. data harga Adapun tujuan penelitian ini akan membahas mengenai model intervensi fungsi step untuk menentukan model terbaik dan meramalkan saham PT. Garuda Indonesia (Persero) Tbk untuk periode berikutnya. Data yang digunakan adalah data harian close price index dari tanggal 2 Januari 2020 sampai dengan tanggal 8 Januari 2021. Berdasarkan penelitian ini diperoleh model intervensi fungsi step terbaik untuk data saham PT. Garuda Indonesia (Persero) Tbk adalah model ARIMA $(3,1,3)$ dengan orde intervensi $b=2, s=0$, dan $r=0$. Pada penelitian menggunakan model tersebut didapatkan hasil peramalan data saham menggunakan model intervensi fungsi step yang berada dalam ambang batas $95 \%$ confidence interval dengan nilai peramalan Root Mean Square Error (RMSE) sebesar 5,02, artinya tingkat kesalahanya 5,02\%.
\end{abstract}

Kata Kunci: COVID-19, GIAA, model intervensi, fungsi step.

\begin{abstract}
The Indonesian aviation industry sector has experienced a significant negative impact due to COVID19. This has worsened the financial performance of airlines in Indonesia, especially resulting in the drop in the close price index of the government-owned airline industry, particularly PT. Garuda Indonesia (Persero) Tbk (GIAA). The intervention model is a time series model that is used to model and predict data that contains intervention from both internal and external factors. Price data. The purpose of this study will discuss the step function intervention model to determine the best model and predict the shares of PT. Garuda Indonesia (Persero) Tbk for the next period. The data used are daily close price index data from January 2, 2020 to January 8, 2021. Based on this research, the best step function intervention model is obtained for PT. Garuda Indonesia (Persero) Tbk is an ARIMA $(3,1,3)$ model with intervention order $b=2, s=0$, and $r=0$. In this study, it was found that the results of stock data forecasting using the intervention model of the step function were $95 \%$ confidence interval threshold with a Root Mean Square Error (RMSE) forecasting value of 5.02, meaning that the error rate is $5.02 \%$.
\end{abstract}

Keywords: COVID-19, GIAA, intervention model, step function. 


\section{Pendahuluan}

Sektor industri penerbangan Indonesia mengalami dampak negatif yang cukup hebat akibat COVID-19, dimana arus penumpang dan kargo mengalami penurunan yang cukup drastis dari Maret 2020 ke April 2020. Hal tersebut membuat performa finansial maskapaimaskapai di Indonesia memburuk, terutama berimbas kepada merosotnya close price index industri penerbangan "Plat Merah", khususnya PT. Garuda Indonesia (Persero) Tbk (GIAA). Adapun beberapa penyebab merosotnya trend demand close price index PT. Garuda Indonesia (Persero) Tbk yaitu mulai dari meningkatnya kasus COVID-19, penerapan PSBB, kondisi new normal, dan kebijakan pemerintah mengenai travel warning. VP Corporate Secretary PT. Garuda Indonesia (Persero) Tbk, Mitra Piranti [1] mengungkapkan, hingga Agustus 2020, terdapat penurunan pada trafik yang diangkut oleh Perseroan baik untuk penumpang maupun kargo diangkut masing-masing sebesar $72 \%$ dan $50 \%$ dibandingkan dengan tahun lalu. Disamping itu, Perseroan juga mengalami penurunan produksi domestik sebesar $55 \%$ dan internasional sebesar $88 \%$ dari tahun lalu.

COVID-19 mengakibatkan terjadinya trend menurun yang signifikan, dimana peristiwa tersebut terjadi diluar kendali. Hal ini mempengaruhi stasioneritas data time series. Peristiwa tersebut dinamakan intervensi. Model intervensi merupakan suatu model time series yang digunakan untuk memodelkan dan meramalkan data yang mengandung intervensi baik dari faktor internal maupun eksternal. Secara umum, ada dua fungsi utama yang digunakan dalam model intervensi, yaitu fungsi step dan pulse. Fungsi step merupakan suatu bentuk intervensi yang bersifat jangka panjang seperti kebijakan pemerintah, kebijakan perusahaan dan travel warning. Sedangkan fungsi pulse merupakan suatu bentuk intervensi yang bersifat sementara dan terjadi hanya dalam kurun waktu tertentu, seperti bencana alam, bom, perang, promo potongan harga, dan demonstrasi [2]. Ada beberapa penelitian yang telah menggunakan analisis intervensi, diantaranya [3] melakukan analisis intervensi fungsi step pada harga saham (studi kasus saham PT. Fast Food Indonesia Tbk). [4] menggunakan analisis intervensi fungsi step pada studi kasus jumlah benda pos pada periode Januari 2006 sampai dengan Februari 2011. [5] menganalisis intervensi fungsi step sekaligus meramalkan kenaikan tarif dasar listrik terhadap besarnya pemakaian listrik. [6] dalam analisis intervensi dan deteksi outlier pada data wisatawan domestik (studi kasus di Daerah Istimewa Yogyakarta).

Dari permasalahan tersebut, dalam penelitian ini akan dibahas mengenai model intervensi fungsi step untuk menentukan model terbaik dan meramalkan data harga saham PT. Garuda Indonesia (Persero) Tbk untuk periode berikutnya. Data yang digunakan pada penelitian ini adalah data harian close price index PT. Garuda Indonesia (Persero) Tbk dari tanggal 2 Januari 2020 sampai dengan tanggal 8 Januari 2021. Tujuan dari penelitian ini adalah membahas mengenai model intervensi fungsi step untuk menentukan model terbaik dan meramalkan saham PT. Garuda Indonesia (Persero) Tbk untuk periode berikutnya.

\section{Tinjauan Pustaka}

\subsection{Model Autoregressive Moving Average (ARIMA(p,dq))}

Deret waktu (time series) adalah serangkaian pengamatan data pengamatan $x_{t}$ yang terjadinya berdasarkan urutan waktu. Pengamatan yang diamati merupakan barisan bernilai diskrit, yang diperoleh pada interval waktu yang sama, misalnya harian, mingguan, bulanan, dan sebagainya. Untuk mendapatkan model dari data yang diperoleh dari pengamatan tersebut diperlukan suatu permodelan time series [7]. 
Deret waktu (time series) adalah serangkaian pengamatan data pengamatan $x_{t}$ yang terjadinya berdasarkan urutan waktu. Pengamatan yang diamati merupakan barisan bernilai diskrit, yang diperoleh pada interval waktu yang sama, misalnya harian, mingguan, bulanan, dan sebagainya. Untuk mendapatkan model dari data yang diperoleh dari pengamatan tersebut diperlukan suatu permodelan time series [7].

Model deret waktu (time series) nonstasioner dikenal sebagai model Autoregressive Integrated Moving Average (ARIMA). Jika orde autoregresive nya $p$, orde selisih/pembeda (differencing) $d$, dan orde moving average nya $q$, maka modelnya ditulis ARIMA (p,d,q) [8]. Model Autoregressive Integrated Moving Average ini didefinisikan sebagai berikut:

Definisi 1. [7] Jika d adalah sebuah bilangan bulat non negatif, maka $\left\{Y_{t}\right\}$ adalah sebuah proses ARIMA $(p, d, q)$ jika $Z_{t}=(1-B)^{d} Y_{t}$ adalah kausal proses ARMA $(p, q)$.

Definisi ini berarti bahwa $\left\{Y_{t}\right\}$ memenuhi sebuah persamaan dalam bentuk

$$
\phi^{*}(B) Y_{t} \equiv \phi_{p}(B)(1-B)^{d} Y_{t}=\theta_{q}(B) e_{t},
$$

$\left\{Y_{t}\right\} \sim \mathrm{WN}\left(0, \sigma^{2}\right)$, dengan $d$ adalah pembeda (differencing), operator autoregressive $\phi_{p}(B)=\left(1-\phi_{1} B-\cdots-\phi_{p} B^{p}\right)$ dan operator moving average $\theta_{q}(B)=\left(1-\theta_{1} B-\cdots-\theta_{q} B^{q}\right)$. Model ARIMA terdiri dari tiga langkah dasar, yaitu tahap identifikasi, tahap estimasi parameter, dan pemeriksaan diagnostik. Selanjutnya model ARIMA dapat digunakan untuk melakukan peramalan. Hasil peramalan model ARIMA sebelum intervensi digunakan untuk mencari nilai residual respons intervensi. Nilai residual tersebut diperoleh dari selisih antara hasil peramalan dengan data pengamatan.

\subsection{Analisis Intervensi Fungsi Step}

Menurut [9], suatu data time series yang dipengaruhi oleh beberapa kejadian eksternal yang disebut intervensi akan mengakibatkan perubahan pola data pada saat waktu $t$. Model intervensi dapat ditulis dalam persamaan berikut:

$$
Z_{t}=f(\beta, I)=\frac{\omega_{s}(B)}{\delta_{r}(B)} B^{b} I_{t}+Y_{t}
$$

dengan,

$$
\begin{array}{lll}
Z_{t} & : & \text { Variabel respons pada waktu } t \\
\omega_{s}(B) & : & \left(\omega_{0}-\omega_{1} B_{1}-\omega_{2} B_{2}-\ldots-\omega_{s} B_{s}\right) \\
\delta_{r}(B) & : & \left(1-\delta_{1} B_{1}-\delta_{2} B_{2}-\ldots-\delta_{r} B_{r}\right) \\
f(\beta, I): & \text { Variabel intervensi } \\
Y_{t} & : & \text { Model noise (model ARIMA pada data sebelum intervensi) } \\
b & : & \text { Waktu tunda mulai berpengaruhnya intervensi } I \text { terhadap } Z \\
s & : & \text { Menunjukkan lamanya suatu intervensi berpengaruh pada data setelah } \\
& & b \text { periode } \\
r & : & \text { Pola efek intervensi setelah } b+s \text { periode sejak kejadian intervensi pada } \\
& \text { waktu ke } T
\end{array}
$$

Analisis intervensi fungsi step digunakan dalam analisis intervensi untuk suatu intervensi yang terjadi pada waktu $\mathrm{T}$ dan memiliki pengaruh jangka panjang [6]. Secara matematis fungsi step dimodelkan sebagai berikut [9]:

$$
I_{t}=S_{t}^{(T)}=\left\{\begin{array}{l}
0, t<T \\
1, t \geq T,
\end{array} \text { dengan } \mathrm{T}\right. \text { adalah waktu intervensi }
$$

Menurut [9], berdasarkan model intervensi pada Persamaan (2) dan model fungsi step pada Persamaan (3), maka model intervensi fungsi step secara umum ditulis sebagai berikut : 


$$
Z_{t}=f(B, I)=\frac{\omega_{s}(B)}{\delta_{r}(B)} B^{b} S_{t}^{(T)}+Y_{t}
$$

Apabila model intervensi diperoleh dari data hasil transformasi $(\lambda)$, maka dapat ditulis sebagai berikut:

$$
Z_{t}(\lambda)=f(B, I)=\frac{\omega_{s}(B)}{\delta_{r}(B)} B^{b} S_{t}^{(T)}+Y_{t}
$$

\section{Metodologi Penelitian}

Penelitian ini menggunakan data sekunder yang diambil dari website www.finance.yahoo.com [10] yaitu data harian close price saham PT. Garuda Indonesia (Persero) Tbk periode 2 Januari 2020 sampai dengan 8 Januari 2021 sebanyak 245 data. Data ini mengalami penurunan dalam waktu yang cukup panjang sehingga diduga model intervensi yang digunakan adalah model intervensi fungsi step, dengan titik terendahnya pada tanggal 23 Maret $2020(\mathrm{~T}=58)$.

Adapun langkah-langkah untuk memodelkan intervensi fungsi step sebagai berikut :

1. Pengelompokkan data

Data dibagi menjadi 2 kelompok berdasarkan waktu terjadinya intervensi :

a. Data sebelum intervensi, dari tanggal 2 Januari 2020 sampai dengan 20 Maret 2020 sebanyak $n_{1}=57$ data.

b. Data saat terjadinya intervensi sampai data terakhir, dari tanggal 23 Maret 2020 sampai dengan 8 Januari 2021 sebanyak $n_{2}=188$ data.

2. Pemodelan ARIMA untuk data sebelum terjadi intervensi.

3. Melakukan uji signifikansi parameter, dan independensi residual, serta uji normalitas residual dengan menggunakan uji Kolmogorov Smirnov.

4. Evaluasi model ARIMA sebelum intervensi berdasarkan nilai MSE terkecil.

5. Peramalan untuk data setelah terjadi intervensi dengan menggunakan model ARIMA sebelum intervensi.

6. Menghitung residual yaitu hasil dari pengurangan data asli dikurangi hasil peramalan data menggunakan model ARIMA sebelum intervensi.

7. Menentukan plot grafik nilai residual.

8. Identifikasi respon intervensi yaitu orde $b, s, r$ berdasarkan plot grafik residual.

9. Estimasi parameter model intervensi.

10. Diagnostic checking model intervensi.

11. Peramalan close price saham PT. Garuda Indonesia (Persero) Tbk dengan menggunakan model intervensi yang terbaik.

\section{Hasil dan Pembahasan}

\subsection{Analisa Deskriptif Data Close Price Saham PT.Garuda Indonesia (Persero) Tbk}

Data close price saham PT. Garuda Indonesia (Persero) Tbk merupakan salah satu data time series yang didalamnya terdapat beberapa fluktuasi penurunan dan peningkatan data. Pada Gambar 1, dapat dilihat bahwa terjadi fluktuasi penurunan yang drastis yaitu pada tanggal 23 Maret $2020(T=58)$. Pada akhir bulan Maret 2020 ini merupakan waktu terjadinya intervensi. Hal ini dikarenakan pada tanggal 20 Maret $2020(T=57)$ pukul $00.00 \mathrm{WIB}$, Menteri Luar Negeri Indonesia Retno Marsudi mengumumkan travel warning yaitu mulainya pembatasan Warga Negara Indonesia (WNI) untuk bepergian ke luar negeri dan pembatasan kedatangan Warga Negara Asing (WNA) ke Indonesia kecuali untuk kepentingan yang 
mendesak. Kegiatan pembatasan tentang penyebaran COVID-19 ini juga terjadi di Indonesia yang memberikan dampak negatif pada terjadinya trading halt tanggal 23 Maret 2020 hampir di seluruh bursa saham di Indonesia. Pada tanggal 31 Maret 2020, Presiden menerapkan Pembatasan Sosial Berskala Besar (PSBB) total untuk seluruh wilayah Indonesia. Hal ini berimbas pada indeks harga saham yang tidak kunjung naik di bulan Maret 2020 hingga April 2020, khususnya di sektor penerbangan. Data close price saham PT. Garuda Indonesia (Persero) Tbk ini kemudian dikelompokkan menjadi dua yaitu data sebelum intervensi untuk waktu $(t<58)$ dan data sesudah intervensi pada waktu $(t \geq 58)$. Data ini akan diolah menggunakan software.

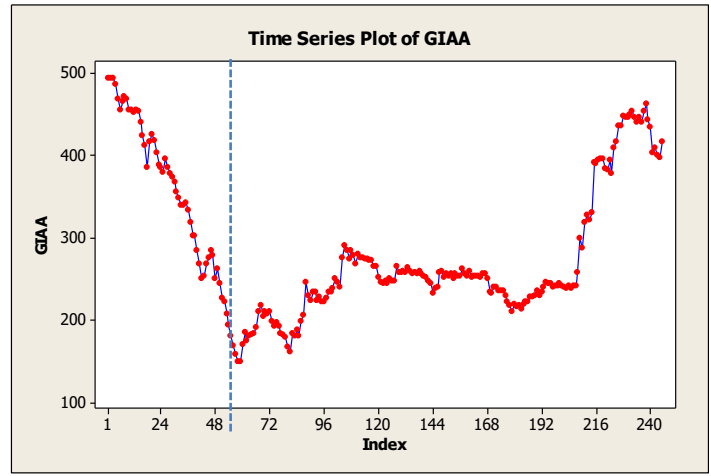

Gambar 1. Plot Data Close Price PT. Garuda Indonesia (Persero) Tbk Tanggal 2 Januari 2020 - 8 Januari 2021

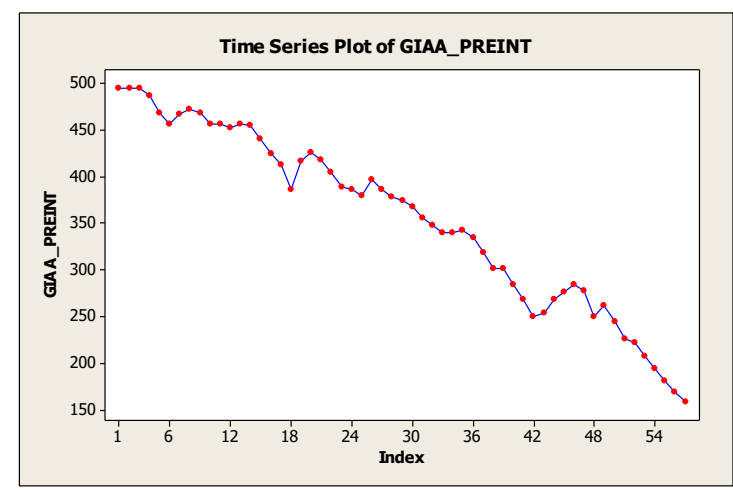

Gambar 2. Plot Data Close Price PT. Garuda Indonesia Sebelum Intervensi $(\mathrm{t}<\mathrm{T}=58)$

\subsection{Pembentukan Model ARIMA pada Data Sebelum Intervensi}

Langkah awal dalam tahapan model analisis intervensi fungsi step, adalah melakukan pembentukan model ARIMA pada data sebelum intervensi $(\mathrm{t}<\mathrm{T})$ yaitu $(\mathrm{t}<58)$. Data yang digunakan pada pembentukan model ARIMA ini adalah data yang telah stasioner, baik itu telah stasioner terhadap varians dan telah stasioner terhadap mean. Pada data close price saham PT. Garuda Indonesia (Persero) Tbk sebelum intervensi pada tanggal 2 Januari 2020 sampai dengan 20 Maret 2020 menggunakan transformasi Box-Cox, diperoleh nilai lamda $\lambda=$ 1 , artinya data tersebut telah stasioner terhadap varians sehingga tidak diperlukan transformasi data. Kemudian pada data tersebut juga dicek stasioneritasnya terhadap mean. Untuk mengecek data stasioner terhadap mean dapat dilihat dengan menggunakan plot Autocorellation Function (ACF). Pada data tersebut dapat dilihat plot ACF pada Gambar 3 menurun perlahan menuju nol, sehingga data tersebut belum stasioner terhadap mean dan diperlukan proses differencing
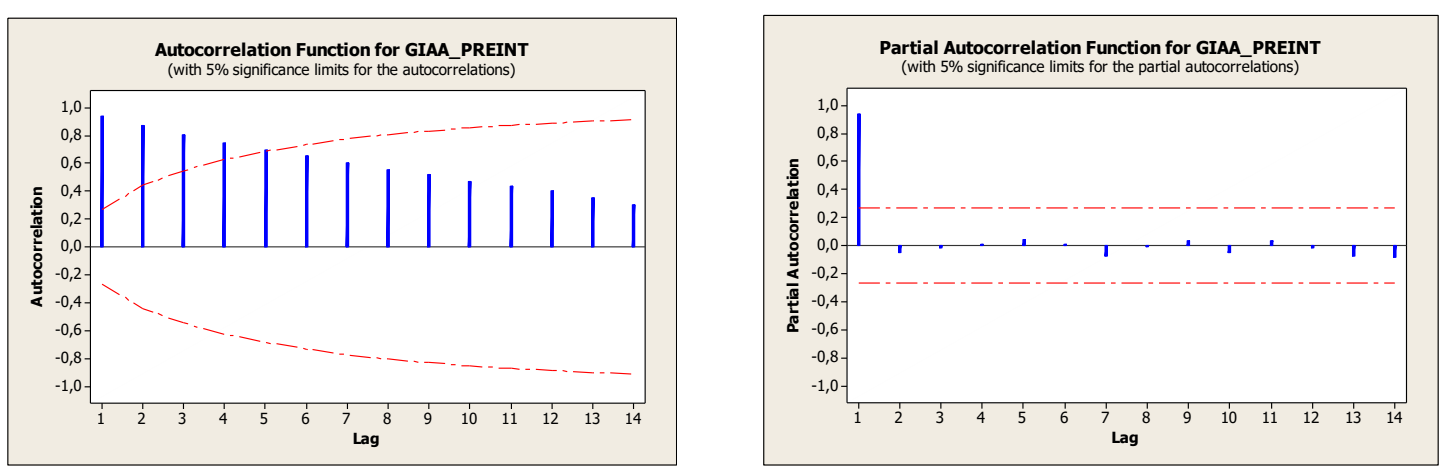

Gambar 3. Plot ACF dan PACF Sebelum Differencing 
Setelah dilakukan differencing pada data close price saham PT. Garuda Indonesia (Persero) Tbk, diperoleh data tersebut telah stasioner terhadap mean. Hal itu dapat dilihat pada Gambar 4 berupa plot data serta plot Autocorrelation Function (ACF) dan Partial Autocorrelation Function (PACF) setelah differencing data. Sehingga data tersebut dapat dikatakan telah stasioner terhadap varians dan mean.
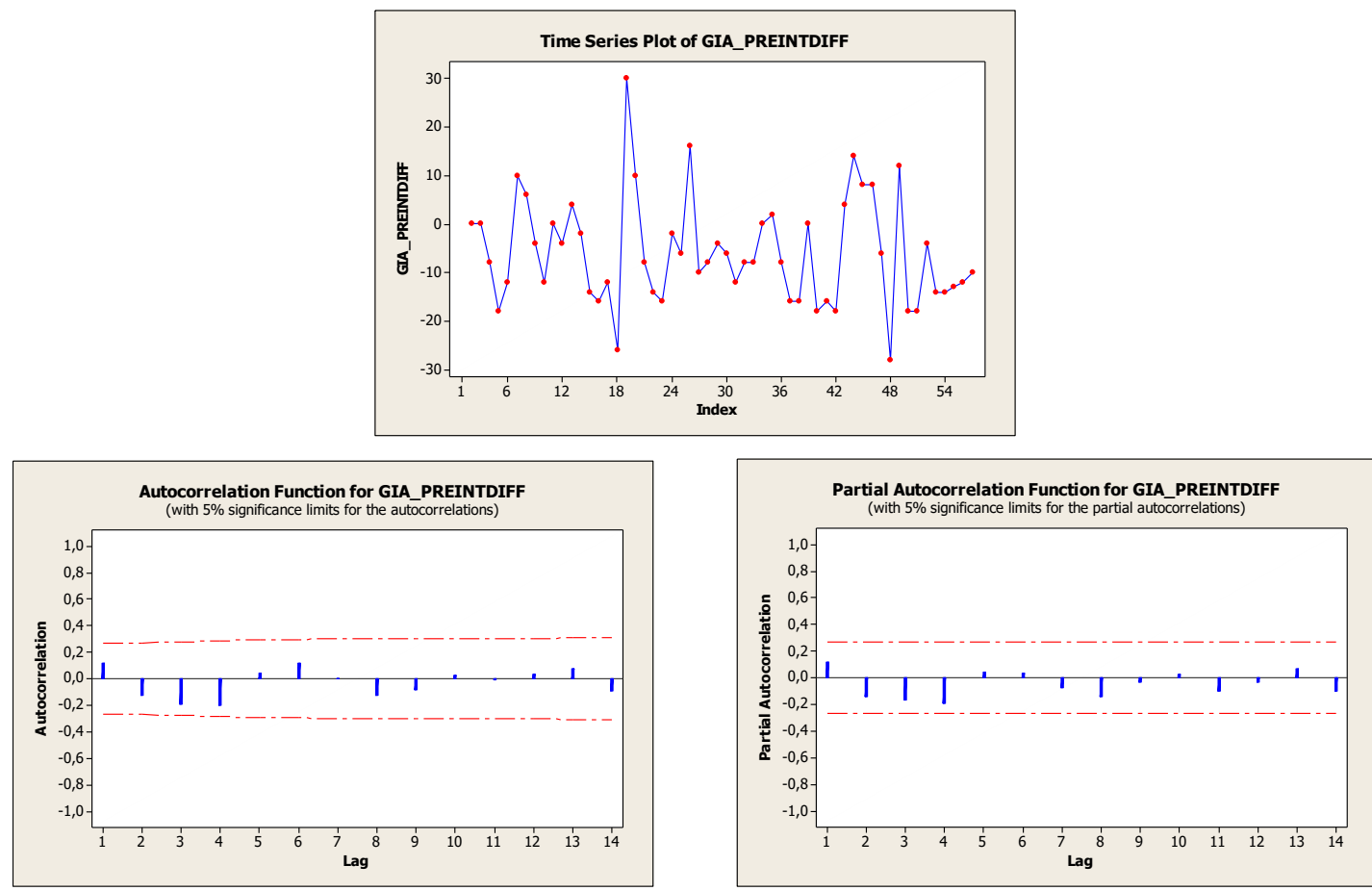

Gambar 4. Plot Data dengan ACF dan PACF Setelah Differencing

Langkah selanjutnya adalah melakukan identifikasi pembentukan model ARIMA untuk data sebelum intervensi yang telah stasioner. Penentuan kemungkinan model ARIMA ini dapat menggunakan plot ACF dan PACF pada Gambar 4. Model ARIMA yang akan dibentuk diantaranya adalah model ARIMA $(0,1,1)$, ARIMA $(1,1,0)$, ARIMA $(1,1,1)$, ARIMA (0,1,2), ARIMA (2,1,0), ARIMA $(1,1,2)$, ARIMA $(2,1,1)$, ARIMA $(2,1,2)$, ARIMA (0,1,3), ARIMA $(1,1,3)$, ARIMA $(2,1,3)$, ARIMA $(3,1,0)$, ARIMA $(3,1,1)$, ARIMA $(3,1,2)$, dan ARIMA (3,1,3). Berdasarkan uji signifikansi parameter, independensi residual menggunakan uji Ljung-Box, dan normalitas residual menggunakan Uji Kolmogorov Smirnov, maka diperoleh model ARIMA $(3,1,3)$ merupakan model yang terbaik dengan nilai parameter yang telah signifikan, tidak ada autokorelasi antar residual, dan telah berdistribusi normal. Secara matematis dapat dinyatakan dalam bentuk :

$$
\begin{aligned}
\phi_{p}(B)(1-B)^{d} Y_{t} & =\theta_{q}(B) e_{t} \\
Y_{t} & =\frac{\theta_{q}(B) e_{t}}{\phi_{p}(B)(1-B)^{d}} \\
Y_{t} & =\frac{\left(1+\theta_{1} B+\theta_{2} B^{2}+\theta_{3} B^{3}\right) e_{t}}{\left(1-\phi_{1} B-\phi_{2} B^{2}-\phi_{3} B^{3}\right)(1-B)} \\
Y_{t} & =\frac{\left(1+1,6411 B-1,1721 B^{2}+0,5495 B^{3}\right) e_{t}}{\left(1-1,6555 B+1,3933 B^{2}-0,5807 B^{3}\right)(1-B)}
\end{aligned}
$$


Model ARIMA (3,1,3) merupakan model terbaik sebelum intervensi, langkah selanjutnya dilakukan peramalan dengan model ARIMA tersebut untuk 20 data setelah intervensi yaitu data harga saham PT. Garuda Indonesia (Persero) Tbk dari tanggal 23 Maret 2020 sampai dengan 21 April 2020. Dari Gambar 1, pada saat terjadinya intervensi yaitu $\mathrm{T}=$ 58 , terdapat penurunan harga saham setelah waktu intervensi. Hal ini mengindikasikan bahwa pola respons yang terjadi adalah perubahan abrupt (secara kasar) dan permanent (tetap ada) setelah terjadinya intervensi.

\subsection{Pembentukan Model Intervensi Fungsi Step}

Hasil peramalan model ARIMA sebelum intervensi digunakan untuk mencari nilai residual respons intervensi. Nilai residual tersebut diperoleh dari selisih antara hasil peramalan dengan data pengamatan. Penentuan garis signifikansi pada diagram residual respons intervensi didapatkan dari perhitungan dua kali nilai standar deviasi residual model ARIMA. Dalam penelitian ini, dari model terbaik ARIMA $(3,1,3)$ nilai dari garis signifikansi pada diagram respon residualnya adalah $\pm 20,06$, dapat dilihat pada Gambar 5 .

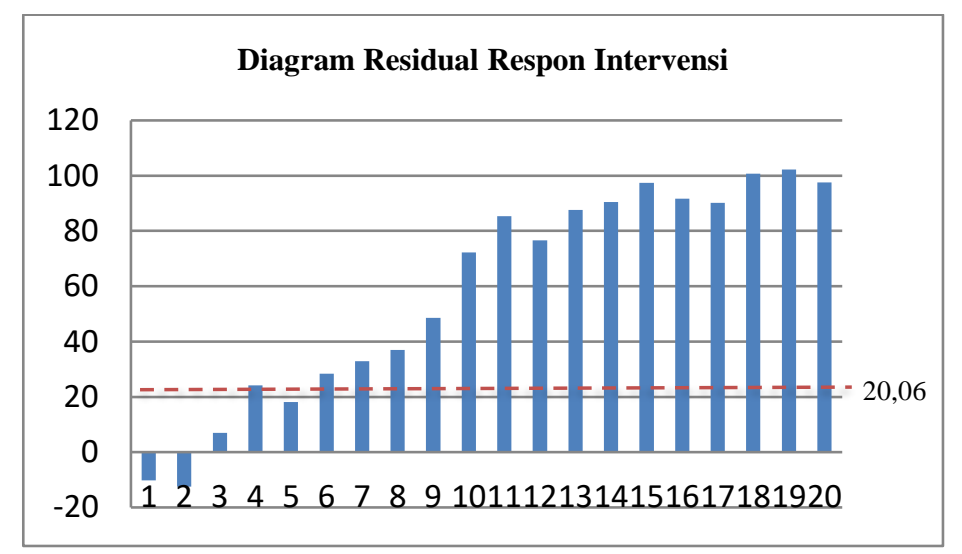

Gambar 5. Diagram Respon Residual Intervensi

Gambar 5 menunjukkan terdapat beberapa respon intervensi yang keluar dari batas atas sebesar $2 \sigma$ atau sama dengan 20,06. Hal ini menyebabkan munculnya beberapa kombinasi $b$, $\mathrm{s}$, dan $\mathrm{r}$ sehingga diperlukan proses coba-coba untuk mencari orde terbaik sebagai orde pembentuk model intervensi. Metode Ordinary Least Squares (OLS) digunakan untuk mengestimasi nilai parameter intervensi. Beberapa model intervensi dicobakan dengan orde $b$ $=1, \mathrm{~s}=0, \mathrm{r}=0 ; \mathrm{b}=1, \mathrm{~s}=1, \mathrm{r}=0 ; \mathrm{b}=2, \mathrm{~s}=0, \mathrm{r}=0 ; \mathrm{b}=2, \mathrm{~s}=1, \mathrm{r}=0 ; \mathrm{b}=3, \mathrm{~s}=0, \mathrm{r}=0 ; \mathrm{b}=$ $3, s=1, r=0 ; b=4, s=0, r=0 ;$ dan $b=4, s=1, r=0$.

Tabel 1. Estimasi Paremeter Model Intervensi

\begin{tabular}{ccccc}
\hline Parameter & Estimasi & Standar error & $\boldsymbol{t}$-value & $\boldsymbol{p}$-value \\
$\omega_{0}$ & 0.88679 & 0.32644 & 2.72 & 0.0071 \\
\hline
\end{tabular}

Setelah dilakukan proses estimasi parameter untuk model intervensi dengan orde $\mathrm{b}=2, \mathrm{~s}=0, \mathrm{r}=0$, diperoleh nilai estimasi parameter $\omega_{0}=0,88679$ dapat dilihat pada Tabel 1. Model intervensi dengan orde $b=2, s=0, r=0$ juga telah memenuhi semua asumsiasumsi parameter signifikan, independensi residual, berdistribusi normal. Sehingga model 
terbaik yang dapat digunakan adalah model ARIMA $(3,1,3)$ dengan orde $b=2, s=0, r=0$ dengan persamaan sebagai berikut:

$$
\begin{aligned}
Z_{t}(\lambda)=f(B, I) & =\frac{\omega_{s}(B)}{\delta_{r}(B)} B^{b} S_{t}^{(T)}+Y_{t} \\
Z_{t}\left(\frac{1}{2}\right)=f(B, I)= & \frac{\omega_{0}(B)}{\delta_{0}(B)} B^{2} S_{t}^{(58)}+\frac{\theta_{q}(B) e_{t}}{\phi_{p}(B)(1-B)^{d}} \\
& =\omega_{0} B^{2} S_{t}^{(58)}+\frac{\left(1+\theta_{1} B+\theta_{2} B^{2}+\theta_{3} B^{3}\right) e_{t}}{\left(1-\phi_{1} B-\phi_{2} B^{2}-\phi_{3} B^{3}\right)(1-B)} \\
Z_{t}\left(\frac{1}{2}\right) & =0.88679 \mathrm{~S}_{\mathrm{t}-2}+\frac{\left(1+1,6411 B-1,1721 B^{2}+0,5495 B^{3}\right) e_{t}}{\left(1-1,6555 B+1,3933 B^{2}-0,5807 B^{3}\right)(1-B)}
\end{aligned}
$$

dimana,

$$
I_{t}=S_{t}^{(58)}=\left\{\begin{array}{l}
0, t<58 \\
1, t \geq 58
\end{array} .\right.
$$

Peramalan dilakukan untuk data harian harga saham PT. Garuda Indonesia (Persero) Tbk dari tanggal 11 januari 2021 sampai dengan 18 Januari 2021 sebanyak 6 data. Hasil peramalan ini dapat dilihat pada Tabel 2.

Tabel 2. Hasil Peramalan Harga Saham PT. Garuda Indonesia (Persero) Tbk Menggunakan Model Intervensi

\begin{tabular}{ccccc}
\hline \multirow{2}{*}{ Periode } & \multirow{2}{*}{ Data Saham } & \multirow{2}{*}{ Forecast } & \multicolumn{2}{c}{ 95\% Confidence Interval } \\
\cline { 4 - 5 } & & & Lower & Upper \\
\hline $11 / 01 / 2021$ & 414 & 415,1 & 389,4 & 441,5 \\
\hline $12 / 01 / 2021$ & 414 & 413,5 & 377,5 & 451,0 \\
\hline $13 / 01 / 2021$ & 412 & 415,0 & 371,2 & 461,4 \\
\hline $14 / 01 / 2021$ & 418 & 414,3 & 362,6 & 469,5 \\
\hline $15 / 01 / 2021$ & 414 & 413,1 & 354,7 & 475,9 \\
\hline $18 / 01 / 2021$ & 402 & 414,3 & 349,8 & 484,2 \\
\hline
\end{tabular}

Dari Tabel 2 dapat dilihat bahwa hasil peramalan data harga saham PT. Garuda Indonesia (Persero) Tbk untuk 6 data harian ke depan menggunakan model intervensi fungsi step berada dalam ambang batas $95 \%$ confidence interval dengan nilai peramalan hampir mendekati sebenarnya hal itu dapat dilihat dari Mean Square Error (MSE) sebesar 25,21 dan nilai Root Mean Square Error (RMSE) sebesar 5,02, artinya tingkat kesalahan pada model peramalan sebesar 5,02\%. Hasil ramalan tersebut dapat digunakan memperkirakan data harian harga saham PT. Garuda Indonesia (Persero) Tbk pasca intervensi akibat adanya kebijakan pemerintah terkait dengan travel warning di masa pandemi COVID-19 yang menyebabkan penurunan saham secara signifikan.

\section{Kesimpulan}

Berdasarkan hasil penelitian yang telah dilakukan, maka dapat disimpulkan bahwa model intervensi fungsi step yang terbaik untuk data saham PT. Garuda Indonesia (Persero) 
Tbk adalah model ARIMA $(3,1,3)$ dengan orde intervensi $b=2, s=0$, dan $r=0$, secara matematis ditulis sebagai berikut:

$$
Z_{t}\left(\frac{1}{2}\right)=0.88679 \mathrm{~S}_{\mathrm{t}-2}+\frac{\left(1+1,6411 B-1,1721 B^{2}+0,5495 B^{3}\right) e_{t}}{\left(1-1,6555 B+1,3933 B^{2}-0,5807 B^{3}\right)(1-B)}
$$

hasil peramalan data harga saham PT. Garuda Indonesia (Persero) Tbk untuk 6 data harian ke depan menggunakan model intervensi fungsi step berada dalam ambang batas $95 \%$ confidence interval dengan nilai peramalan hampir mendekati sebenarnya. Selain itu diperoleh Mean Square Error (MSE) sebesar 25,21 dan nilai Root Mean Square Error (RMSE) sebesar 5,02, artinya tingkat kesalahan pada model peramalan ini kecil.

\section{Daftar Pustaka}

[1] IQPlus. Ini Dampak Pandemi COVID-19 ke Garuda Indonesia. 16 September 2020. https://www.sinarmassekuritas.co.id/ini-dampak-pandemi-covid-19-ke-garudaindonesia. Diakses 13 Januari 2021.

[2] Wei, W.W.S., 2006. Time Series Analysis: Univariate and Multivariate 2nd Edition. New Jersey : Pearson Education.

[3] Sari, R.N., Mariani, S., Handikawati, P. 2016. "Analisis Intervensi Fungsi Step pada Harga Saham (Studi Kasus Saham PT. Fast Food Indonesia Tbk)". UNNES Journal of Mathematics 5(2).

[4] Chrystine, A., Hoyyi, A., Safitri, D. 2014. "Analisis Intervensi Fungsi Step (Studi Kasus pada Jumlah Pengiriman Benda Pos ke Semarang pada Tahun 2006-2011)". Jurnal Gaussian, Vol. 3, No.3, hal. 293-302.

[5] Ekayanti, R., Maria, M.N., Sulistianingsih, E. 2014. “Analisis Model Intervensi Fungsi Step untuk Peramalan Kenaikan Tarif Dasar Listrik (TDL) terhadap Besarnya Pemakaian Listrik". Buletin Ilmiah Mat. Stat. dan Terapannya. Vol. 3, No. 3, hal. 175184.

[6] Budiarti, L., Tarno., Warsito, B. 2013. “Analisis Intervensi dan Deteksi Outlier pada Data Wisatawan Domestik (Studi Kasus di Daerah Istimewa Yogyakarta)". Jurnal Gaussian, Vol.2, No.1.

[7] Brockwell, P.J. dan Davis, R.A. 2002. Introduction to Time Series and Forecasting. Springer-Verlag. New York.

[8] Makridakis, S., Wheelwright, S.C., McGee, V.E. 1988. Metode dan Aplikasi Peramalan, Jilid 1 Edisi Kedua. Ir. Untung Sus Andriyanto, penerjemah. Jakarta. Erlangga. Terjemahan dari: Forecasting, 2nd Edition.

[9] Wei, W.W.S., 1990. Time Series Analysis. Addison Wisley Publishing Company. Canada.

[10] https://finance.yahoo.com/quote/GIAA.JK/history?p=GIAA.JK. Diakses 12 Januari 2021. 